\title{
Tetiana Tkachenko,
}

PhD in Geographical Sciences,

Associate Professor,

Kyiv National University

of Culture and Arts,

Kyiv, Ukraine

todria@ukr.net

https://orcid.org/0000-0001-9447-567X

\section{DEVELOPMENT OF TOURIST-RESOURCING POTENTIAL OF UKRAINE (PRACTICAL ASPECT)}

In the work classification characteristics and features of the main aspects within the complex assessment of the resource subsystem of the recreational potential that determine the state and prospects for the development of Ukraine's tourist-resource potential were established. A methodological basis for solving the tasks was a series of traditional general scientific methods of research and evaluation of tourism and resource potential. In addition abstraction method, method of analysis and synthesis, historical and logical methods, cartographic method, statistical and mathematical method were used. Based on the research carried out, the classification characteristics and main features of the main aspects (within the complex assessment of the resource subsystem of the recreational potential), scientific and tourist and educational and educational purposes, which shape and determine the state and prospects for the development of Ukraine's tourist potential, were determined. The main thing in their spectrum is the creation of a special (national) tourist infrastructure. The main conclusions are formulated. The main criteria of classification characteristics and features of complex estimation that determine the state and prospects of touristresource potential development in Ukraine are determined and proposed. The main criteria of classification characteristics and features of complex estimation, which determine the state and prospects of tourist-resource potential development in Ukraine are determined and proposed. Improvement of the methodical instruction of a comprehensive assessment of Ukraine's tourist-resource potential for the formation of a complete and rational representation of the content of the term and the definition of related concepts were obtained. However, recreation and tourismology have the greatest influence on the formation of the content-terminological characteristics of the concept. Materials of publication, conclusions can be used and implemented during the educational process, training personnel for the national tourism industry, practical activity of tourist companies, for the promotion of recreational geography and tourism.

Keywords: recreation and tourism sphere, estimation of tourist-resource potential, method, recreational and tourist potential, recreational landscape.

Formulation of the problem. An important problem in ensuring the effective functioning of the recreational and tourist spheres is the reliability and integrity of the assessment of the tourist and resource potential of Ukraine. The formation of recreational systems is determined by the recreational needs of a person and society as a whole, and their territorial localization, tied to a large extent by the availability of resources that shape the potential. In order to 
optimize the planning processes for the development of the national recreational sphere, it is necessary to analyze the factors that stimulate the development of the regions, in turn; it will enable the optimal direction and use of capital and resources in the field of recreation to obtain an effective result.

Analysis of recent researches and publications. The research was devoted to some publications of famous figures of domestic and foreign tourism - Nikolaenko D. V., author of the book "Recreational Geography» (2001), Kvartalnov V. A, Beydyk O. O., Bogolyubov S. A., Danilchuk V. F., Kuzik S. P., Kasyanchuk Z. O., Stafiychuk V. I., Tkachenko T. I., Tsaryk L., Chernyuk G., Okhrimenko E. V. and others.

The purpose and objectives of the article is establishing the classification characteristics and features of the main aspects within the framework of the integrated assessment of the resource subsystem of the recreational potential that determines the state and prospects of the development of tourist-resource potential of Ukraine.

Among the tasks are: a) analysis of literary sources, cartographic materials; comparing the views and ideas of various specialists with an effort to systematize existing materials, to identify and indicate the role of tourismrecreational research; b) providing a coherent assessment of the current state of tourism and resource potential of Ukraine; c) detailed and consistent study of documentation of natural, historical and cultural and socio-economic recreational resources, their environmental and scientific significance.

Presenting main material. Despite a large number of scientific papers on the methods and methodology of assessing tourism resource potential, there is currently no single standard methodology that would be universal for all regions of Ukraine. Method (gr. Methodos) - a way of knowing, studying the phenomena of nature and social life. It is also a collection of techniques or operations of practical or theoretical development of reality, subordinate to the study of a particular task. The difference between the method and the theory has a functional character. Formulated as the theoretical result of the previous study, the method serves as the starting point and condition for a future research. In the most general sense, the method is a way, a way of achieving the goal and objectives of the study.

The general scientific methods of research include: empirical (experiment, observation, description) and theoretical (analysis, synthesis, abstraction, generalization, induction, deduction, explanation, systematization, classification, etc.) methods: abstraction method, method of analysis and synthesis, historical and logical methods, cartographic method, statisticalmathematical method.

The method of abstraction consists of knowing the real tourist processes by separating the main, most important, fixed sides of a certain phenomenon abstracted from all the casual, insignificant.

The method of analysis and synthesis is used in the unity of its two components. In the analysis, the object of the study is decomposed into the constituent parts (parts of the object, its features, properties, relations), each of which is studied separately. In the synthesis there is an association of various elements, sides of the object into a single entity, taking into account the interrelationship between them. 
Historical and logical methods are used to study economic processes in unity. The historical method studies these processes, their development in chronometric sequence, in which they arose, developed and changed one after another. The logical method explores the tourist processes in their logical sequence, going from simple to complex, freeing at the same time from randomness and unnecessary details that are not inherent in this process.

Cartographic method of research - a method of applying maps for scientific and practical knowledge of the phenomena depicted on them. The cartographic method is used to study the patterns of spatial arrangement of phenomena, their interrelationships, dependencies and development.

The map method can be grouped into the following main groups: visual analysis, consisting of direct visual study of maps in spatial placement, combinations, connections, and dynamics of phenomena; graphical methods of analysis based on the mapping of profiles and sections (provide a visual representation of the vertical structure of phenomena), block diagrams (combining a perspective image of the terrain with its vertical cuts), different kinds of charts and diagrams, etc.; card metric work consisting in determining the coordinates, distances, lengths, heights, squares, volumes, angles and other quantitative characteristics of the objects depicted on the map with an assessment of the accuracy of the results obtained by the maps.

The statistical-mathematical method of research is used to study maps of any homogeneous phenomena (air temperatures, density of rural population, yields, etc.), their placement and temporal changes that are caused by many factors with unknown functional dependence, to find out the form and tightness of the links between different phenomena.

Recreational and tourist resources are objects and phenomena of nature of anthropogenic origin, which have qualitative and quantitative parameters favorable for recreational activity and serve as a material basis for the territorial organization of recreation, health improvement and treatment of people, the formation of recreational areas (centers), their specialization and economic efficiency (Ковальська, 2016).

The recreational potential of the territory consists of two equal parts: social and natural, which exist in a particular spatial-temporal reference system and are used for rest, recreation and for the organization of recreational activities (Ковальська, 2014).

The recreational aspect of Ukrainian relief is closely linked with the same aspects of other environmental elements.

Usually, when assessing the possibilities to use geomorphologic phenomena in the process of developing tourist routes, a large share falls on the uniqueness of geologic phenomena. And there is nothing unusual in this, because the unique aesthetic and recreational features of geomorphologic phenomena are formed on the background of the interaction of endogenous and exogenous factors in the formation of relief (Ковальська, 2010).

The following components of recreational and tourist resources are distinguished in order to determine the estimation of risk and resource potential: natural RTRs, socio-historical RTRs and natural and human-made RTRs. Also, 
the researchers singled out such RTRs as super touch-tour and trans-resource objects that combine several of the above-mentioned RTR components. Their potential is a combination of these components (Бейдик, 2009).

Estimation of recreational and tourist resources is determined by the ratio of the object and subject, which includes the following stages:

- allocation of the object of evaluation;

- allocation of the subject of assessment (recreation, recreation and tourism);

- formation of criteria for evaluation, depending on the scale and purpose of the study, the properties of the object;

- development of parameters (assessment scales).

Recreational resources are determined by qualitative and quantitative indicators. When quantified, an important issue is the development of assessment scales, although not all researchers of the problem share this approach to the assessment of recreational and tourist resources. The most popular are grades 3-7, where the most favorable conditions are rated at the highest point.

According to the three main points of the subject, there are three types of assessment of recreational and tourist resources: medical and biological; psycho-aesthetic; technological.

Medico-biological type determines the influence of natural factors on the human body and is essential for the assessment of climatic recreational resources that significantly affect the health of humans.

The psychological and aesthetic type of evaluation determines the emotional impact on a person of certain features of the natural landscape and other recreational resources. The methodology of such an assessment is complex and not enough developed. It's reduced mainly to the definition of human emotional response (psycho emotion) to the natural-territorial complex.

The psycho-aesthetic assessment of the territory takes into account:

- the degree of contrast (the most attractive for recreation are edge zones, for example, on the border of various elements of natural-territorial complexes);

- landscape saturation (landscape morphology);

- forest area;

- exotics (measure of contrast between place of residence and recreation area);

- uniqueness (a measure of the uniqueness of objects and phenomena);

- attraction.

Technological type of assessment takes into account the interaction of a person and the environment through the «technology» of recreational activities, where the subject is the recreational industry. Such an assessment includes two aspects: the possibilities for realization of one or another type of recreational-tourist activity and prospects of engineering and construction development of the territory. An important indicator of technological evaluation is the recreational capacity of the territory (resource). 
One of the complex indicators of the medical-biological type of evaluation of recreational resources is the system of effective temperatures, which includes air temperature, relative humidity, wind speed, solar radiation, and long-wave radiation.

The assessment of balneal resources is based on medical-biological and technological approaches. In this case, both quantitative and qualitative indicators, which are the basis of classification and typing of balneal resources, are used.

Thus, mineral waters are divided according to their mineralization: fresh (up to $2 \mathrm{~g} / \mathrm{l}$ ), low mineralization ( $2-5 \mathrm{~g} / \mathrm{l})$, average mineralization $(5-15 \mathrm{~g} / \mathrm{l})$, high mineralization (15-35 g/l ) and brines (more than $35 \mathrm{~g} / \mathrm{l}$, some sources - more than $50 \mathrm{~g} / \mathrm{l})$. At the same time, drinking medical table waters include water with mineralization of $1-10 \mathrm{~g} / \mathrm{l}$. There are 9 basic balneal groups for classification of mineral water in a set of indicators: mineral waters, the therapeutic effect of which is determined by the ionic composition and the degree of mineralization; carbon dioxide; hydrogen sulfide (sulfide); glandular; bromine, iodine, iodine-bromine; siliceous (thermal); radon (radioactive); boron (Ковальська, 2014).

The general indicators that determine the recreational features of reservoirs are their availability, purity, size, depth. The most recreational value is warm seas, lakes, reservoirs, large rivers with a temperature of $+17^{\circ} \mathrm{C}$ for 2-3 months. The larger the reservoir is, the wider the range of their recreational use.

An important component of recreational and tourist resources is the landscape, in accordance with - the basis of the landscape - relief. The relief of the earth's surface of Ukraine as a basic element of the natural complex greatly affects the nature of recreational activities. In its general features, the relief of Ukraine determines the recreational specialization of the territory (plains - mountains - coastal seas, reservoirs - large river systems), and in some cases, the main natural object, on which the recreation system itself is based (Ковальська, 2010).

In analyzing the aesthetic properties of the landscape, the greatest importance is its expressiveness, that is, the presence of such components that are most attracted by the attention and admiration of the observer (forms and types of relief, hydrological objects, the nature of the distribution of vegetation, anthropogenic objects, etc.).

The number and combination of the components of the landscape and the nature of their distribution determine the type of landscape. In this case, mesoreliefs with different types of vegetation are of particular importance, which can increase or weaken the expressiveness of individual components of the landscape. In particular, the visual perception of the expressiveness of the relief and large water surfaces depends on the type of vegetation.

- depending on the peculiarities of the aesthetic impact of the landscape on a person, scientists distinguish the following categories, in particular;

- the degree of human transformation of the natural environment; 
- on a degree of uniformity (pictorial - a harmonious combination of the optimal for perception of the number of components of the landscape, monotone - the presence of insignificant objects of the same type);

- expert assessments of experts or according to sociological data (unique, rare, attractive, unattractive, unappealing, degraded);

- on the features and number of complicated formations of the main landscape-forming factors (the density and depth of the dismemberment of the relief, the presence and diversity of the hydrological objects, the diversity of the flora and fauna of the territory, the aesthetically «inscribed» anthropogenic objects, as well as the natural and man-made panoramas available for observation).

Aesthetic evaluation involves the identification of aesthetic properties (natural and cultural attractiveness) of territorial combinations (landscapes) and degree of interest. It evaluates the emotional impact of various components of the landscape on a person. Indicators of assessment can be both subjective and objective. It is important to search for different methods of assessment based on objective evidence.

The basis of evaluation is the consistency and degree of natural factors action that have an effect on the organs of vision and the whole complex of sensations (the shape of the terrain surface, the nature of the distribution of vegetation, human-made objects, etc.). The aesthetic value of the landscape depends on the diversity of landscape elements. The variety of landscape determines the potential richness of visual images. In the diversity of the landscape, not only the properties of the assessed territory (internal variety) can be reflected, but also the properties of the neighboring territories that are perceived visually (external variety).

The therapeutic and improving function is largely due to the phytoncidity of the forest that is its bactericidal, fungicidal action. The measure of fitocidity (depending on tree species), reaches its maximum in the spring-summer period (flowering and active plant growth), but decreases - in autumn. Recreational forests as a component of natural recreational resources are just a small part of the forest ecosystems that provides the population with treatment, recreation and tourism. Recreational activities are determined by meaningful diversity and can vary.

Natural-manmade TPP or nature-protected areas are formed from: wildlife sanctuaries, national natural parks, regional landscape parks, biosphere reserves, nature reserves, nature tracts, nature monuments, and parks, monuments of garden art, botanical gardens, dendrological and zoological parks. This is an important criterion for assessing the recreational level of the region. The assessment of the nature reserves is established by measuring the percentage to the total area of the territory, the assessment of which is carried out, as well as the qualitative characteristics of specific protected areas.

Identification and assessment of natural recreational and tourist resources is one of the main tasks of the recreational nature usage management. Only after the implementation of these studies can establish the natural and 
recreational potential of the territory (water areas), on the basis of which development of recreation and management development plans are underway.

Conclusions: Methodological basis for the tasks solving was a series of traditional general scientific methods of research and evaluation of tourism and resource potential. Based on the research carried out, the classification characteristics and main features of the main aspects (within the complex assessment of the resource subsystem of the recreational potential), scientific and tourist and educational and educational purposes, which form and determine the state and prospects of the development of Ukraine's tourist potential, were determined, the main issue in their spectrum is the creation of a special (national) tourist infrastructure.

\section{сПИСОК ПОСИЛАНЬ}

Бейдик, О.О. (2009). Рекреаційні та туристичні ресурси України. Київ: АльтерПрес.

Ковальська, Л.В. (2010). Рекреаційна оцінка місцевості території Галицького національного парку. Фізична географрія та геоморфологія, 1 (58).

Ковальська, Л.В. (2013). Екотуризм. Івано-Франківськ: НАІР.

Ковальська, Л.В. (2014). Рекреаційна географрія. Івано-Франківськ: НAIP.

Ковальська, Л.В. (2016). Географрія туризму. Івано-Франківськ: HAIP.

Стафрійчук, В.І. (2008). Рекреалогія (2-ге вид.). Київ: АльтерПрес.

Ткаченко, Т.І. (2011). Рекреаційні властивості рельєфу України як складової формування духовності українського етносу. В Рекреаційний потенціал Карпатського регіону: історія, сучасний стан, перспективи, Матеріали Міжнародної наукової конференції Івано-Франківськ - Яремче (19-21 жовтня 2011 р.) (Вип. 3, с. 494-500). Івано-Франківськ: Фоліант.

Ткаченко, Т.І. (2013). Рекреаційна спеціалізація рельєфу України в системі «рельєф-рекреація» як складова формування духовності українського етносу. Фізична географрія та геоморфологія, 4 (72), 32-41.

\section{REFERENCES}

Beidyk, O.O. (2009). Rekreatsiini ta turystychni resursy Ukrainy [Recreational and tourist resources of Ukraine]. Kyiv: AlterPres [in Ukrainian].

Kovalska, L.V. (2010). Rekreatsiina otsinka mistsevosti terytorii Halytskoho natsionalnoho parku [Recreational assessment of the terrain of the territory of the Galician National Park]. Fizychna heohrafiia ta heomorfolohiia, 1 (58) [in Ukrainian].

Kovalska, L.V. (2013). Ekoturyzm [Ecotourism]. Ivano-Frankivsk: NAIR [in Ukrainian].

Kovalska, L.V. (2014). Rekreatsiina heohrafiia [Recreational geography]. Ivano-Frankivsk: NAIR [in Ukrainian].

Kovalska, L.V. (2016). Heohrafiia turyzmu [Geography of tourism]. IvanoFrankivsk: NAIR [in Ukrainian].

Stafiichuk, V.I. (2008). Rekrealohiia [Reclamation] (2nd ed.). Kyiv: AlterPres [in Ukrainian]. 
Tkachenko, T.I. (2011). Rekreatsiini vlastyvosti reliefu Ukrainy yak skladovoi formuvannia dukhovnosti ukrainskoho etnosu [Recreational properties of relief of Ukraine as a component of the formation of the spirituality of the Ukrainian ethnos]. In Rekreatsiinyi potentsial Karpatskoho rehionu: istoriia, suchasnyi stan, perspektyvy [Recreational potential of the Carpathian region: history, current state, prospects], Proceedings of the International scientific conference Ivano-Frankivsk - Yaremche (October 19-21, 2011) (Issue 3, pp. 494-500). Ivano-Frankivsk: Foliant [in Ukrainian].

Tkachenko, T.I. (2013). Rekreatsiina spetsializatsiia reliefu Ukrainy v systemi «relief-rekreatsiia» yak skladova formuvannia dukhovnosti ukrainskoho etnosu [Recreational specialization of relief of Ukraine in the system of «relief-recreation» as a component of the formation of the spirituality of the Ukrainian ethnos]. Fizychna heohrafiia ta heomorfolohiia, 4 (72), 32-41 [in Ukrainian].

\title{
УДК 338.483.1(477)
}

\author{
Тетяна Ткаченко, \\ кандидат географічних наук, доцент, \\ Київський національний університет \\ культури і мистецтв, \\ Київ, Україна \\ todria@ukr.net \\ https://orcid.org/0000-0001-9447-567X
}

\section{РОЗВИТОК ТУРИСТИЧНО-РЕСУРСНОГО ПОТЕНЦІАЛУ УКРАЇНИ (ПРАКТИЧНИЙ АСПЕКТ)}

У статті визначено та запропоновано основні критерії класифікаційних характеристик та особливостей комплексної оцінки туристично-ресурсного потенціалу, що визначають стан та перспективи розвитку туризму в Україні. Удосконалено методичну інструкцію комплексної оцінки туристично-ресурсного потенціалу для формування повного та раціонального визначення ії̈ змісту та відповідних концепцій. Методологічною основою для вирішення завдань була серія традиційних загальнонаукових методів дослідження та оцінки туристичного та ресурсного потенціалу. Проте найбільший вплив на формування змістовнотермінологічних характеристик концепції чинять рекреація та туризм. Встановлено, що у межах комплексної оцінки ресурсно-рекреаційної системи головну роль відіграє наявність та стан матеріально-технічний засобів й (національна) туристична інфрраструктура в цілому. Надано сучасну характеристику питанням паспортизації та оцінки природних рекреаційнотуристичних ресурсів, що $€$ одним із головних завдань менеджменту рекреаційного природокористування, що формують, впливають та визначають стан та перспективи розвиток туристичного потенціалу України. Доведено, що аналіз туристично-ресурсного потенціалу території (акваторії) $€$ вихідною науковою базою для розробки стратегії та планів розвитку туризму на державному та регіональному рівнях. Визначено та запропоновано основні критерії класифікаційних характеристик та особливостей комплексної оцінки, що визначають стан та перспективи розвитку туристично-ресурсного потенціалу України. На підставі отриманих результатів розроблено низку практичних 
рекомендацій, що можуть бути використано під час навчального процесу, підготовки кадрів для національної туристичної галузі, практичної діяльності туристичних компаній, для просування рекреаційної географії та туризму.

Ключові слова: рекреаційна та туристична галузь, оцінка туристичноресурсного потенціалу, метод, рекреаційний та туристичний потенціал, рекреаційний ландшафт.

$\overline{\text { (c) Tkachenko T., } 2018}$ 